\title{
AN IMPROVED FLAME-PHOTOMETRIC METHOD FOR DETERMINING CALCIUM IN SERUM
}

\author{
BY \\ J. W. WOOLLEN AND P. G. WALKER \\ From the Biochemistry Department, Institute of Orthopaedics, Stanmore, Middlesex
}

(RECEIVED FOR PUBLICATION SEPTEMBER 2, 1958)

Powell (1953) introduced a method for the estimation of serum calcium using the EEL flame photometer, and claimed that it gave results in good agreement with a standard titrimetric procedure.

In this laboratory, both these methods were found to give low results when tested against standard sera, prepared by adding known amounts of calcium to serum completely decalcified by treatment with a cation exchange resin. The cause of these low results has been established, and modified procedures for avoiding them have been developed.

\section{Materials}

Resin.-Amberlite XE-66B (Charles Lennig \& Co., Ltd., London) was used in the sodium form. The resin $(50 \mathrm{~g}$.) was prepared by treatment with 1 litre volumes of (1) $6 \mathrm{~N} \mathrm{HCl,} \mathrm{(2)} \mathrm{water} \mathrm{(twice),} \mathrm{(3)} 2 \mathrm{~N}$ $\mathrm{NaOH}$, and (4) water (twice), this sequence being repeated until the supernatant from the $\mathrm{HCl}$ treatment was colourless. After the next $\mathrm{NaOH}$ treatment, the resin was washed until the washings were neutral and chloride-free, and then air dried.

Sera of Known Calcium Content (Standard Sera).Pooled human serum $(100 \mathrm{ml}$. $)$ was decalcified by shaking with three successive batches of "amberlite XE-66B " (sodium form, $4 \mathrm{~g}$.). Sera of known calcium content (8-16 mg./100 ml.) were prepared by evaporating to dryness aliquots of a standard solution of calcium chloride, and re-dissolving the residue in suitable volumes of decalcified serum. The standard calcium solution $(10 \mathrm{mg}$. $\mathrm{Ca} / 100 \mathrm{ml}$.) was prepared by dissolving $0.250 \mathrm{~g}$. anhydrous calcium carbonate (AR, dried at $100-110^{\circ} \mathrm{C}$.) in the minimum amount of concentrated $\mathrm{HCl}$, and diluting to 1 litre with water.

All analyses were carried out in duplicate. The titrimetric and flame photometric methods of Powell (1953) were used; the only modification was that precipitation of calcium oxalate was allowed to proceed overnight. Although Powell's titrimetric procedure is stated to be that of Clark and Collip (1925), it is, from his description, obviously that of Tisdall (1923).

\section{Improved Flame Photometric Method}

Reagents.-Water which had been passed through an "elgastat" deionizer was used for all reagents, standards, and dilutions.

Trichloroacetic Acid Solution.-10\% w/v.

Oxalate Precipitant.-Oxalic acid, 0.63 g., 13.50 g. ammonium oxalate, and $50 \mathrm{~g}$. ammonium acetate (all AR) are dissolved to 1 litre with water.

Triton $X-100$ (Charles Lennig \& Co., Ltd., London). $-2 \% \mathrm{v} i \mathrm{v}$.

Solvent for Oxalate Precipitant.-Perchloric acid (AR, 72\%) $0.71 \mathrm{ml}$., and $10 \mathrm{ml}$. " triton X-100" solution are diluted to $100 \mathrm{ml}$. with water.

Blank Solution.-Equal volumes of solvent and absolute ethanol.

Stock Calcium Standard.-Calcium carbonate (AR, dried at $100-110^{\circ}$ C.), 0.250 g., and $7.1 \mathrm{ml}$. perchloric acid (AR, 72\%) are made up to 1 litre with water.

Working Calcium Standard.-Stock standard, 10 ml., and $4 \mathrm{ml}$. " triton X-100" solution are made up to $40 \mathrm{ml}$. with water and mixed with $40 \mathrm{ml}$. absolute ethanol. This solution is freshly prepared for each batch of determinations and allowed to cool to room temperature before use.

Procedure for Serum.-Trichloroacetic acid $(4 \mathrm{ml}$.) is added to $2 \mathrm{ml}$. serum and $4 \mathrm{ml}$. water in a centrifuge tube, mixed, and, after standing $20 \mathrm{~min}$., centrifuged at 2,000 r.p.m. for $20 \mathrm{~min}$. Duplicate aliquots (2.5 $\mathrm{ml}$.) of clear supernatant are transferred to centrifuge tubes $(15 \mathrm{ml}$. capacity) and mixed with $4 \mathrm{ml}$. oxalate precipitant and $0.6 \mathrm{ml}$. " triton X-100." After standing overnight, each tube is again centrifuged as above, and the supernatant decanted. The tube is drained by standing inverted for $1 \mathrm{~min}$. on Whatman No. 42 filter paper and the mouth of the tube dried with the same paper. The precipitate is dissolved with agitation in $2 \mathrm{ml}$. solvent and the solution is mixed with $2 \mathrm{ml}$. ethanol. This solution is then sprayed in the flame photometer, set to zero with the blank solution and the sensitivity adjusted so that the working standard reads 50 . The volume of the solution is sufficient to permit two or three readings to be taken if required. Under these conditions

Serum calcium $=\frac{\text { Test reading }}{\text { Standard reading }} \times 10 \mathrm{mg} . / 100 \mathrm{ml}$. 
Procedure for Urine, Faeces, and Food.-The method described above is used without modification for the estimation of calcium in urine. The sample volume (usually $2 \mathrm{ml}$.) may be altered in cases where excretion is abnormal.

Faeces, or food, is homogenized in water and the homogenate weighed. Aliquots, weighed into silica crucibles, are dried in a vacuum oven, and ashed overnight at $550^{\circ} \mathrm{C}$. The ash is dissolved in $6 \mathrm{~N}-\mathrm{HCl}$ and made up to a suitable volume with water. Calcium in aliquots of this solution is estimated as in the trichloroacetic acid extracts described above.

\section{Results and Discussion}

Accuracy of Standard Sera.-The calcium concentration of a standard serum will be correct only if the serum is completely decalcified before the addition is made. Stefanini (1948) and Hussey, Quick, Stefanini, Consolazio, and Sargent (1950) found that serum could be completely decalcified with the cation exchange resin " amberlite IR-100." Amberlite XE-66B, a finely divided form of a resin of greater exchange capacity, should act similarly.

The efficiency of the decalcification procedure was tested in various ways. No titratable oxalate precipitate could be detected in serum treated as described above by the Tisdall (1923) method. This finding merely sets an upper limit of about $0.5 \mathrm{mg}$. $/ 100 \mathrm{ml}$. for the residual calcium (Sendroy, 1944).

Samples of decalcified serum and of a standard solution of calcium containing $0.05 \mathrm{mg} . / 100 \mathrm{ml}$. were ashed. The ash was dissolved in one tenth of the original volume and estimated for calcium. Whereas the recovery of calcium in the latter was complete, the former again gave no titratable oxalate precipitate, showing that the calcium concentration in the treated serum was less than $0.05 \mathrm{mg}$. $/ 100 \mathrm{ml}$.

Flame photometric estimations of standard calcium solutions with and without the addition of protein-free extract from treated serum showed that the latter contained less than $0.1 \mathrm{mg}$. $\mathrm{Ca} / 100 \mathrm{ml}$.

Additions of calcium equivalent to $10 \mathrm{mg} . / 100$ $\mathrm{ml}$. were made to samples of serum removed after each of five consecutive treatments with resin.

TABLE I

DECALCIFICATION OF SERUM BY SUCCESSIVE RESIN TREATMENTS

\begin{tabular}{l|c|c|c|c|c|c}
\hline No. of treatments before sampling & 0 & 1 & 2 & 3 & 4 & 5 \\
\hline Calcium content (mg./100 ml.).. & 19 & 11 & $10 \cdot 1$ & $10 \cdot 1$ & $10 \cdot 1$ & 101 \\
\hline
\end{tabular}

The equivalent of $10 \mathrm{mg}$. calcium $/ 100 \mathrm{ml}$. was added to each sample before estimation.
The results of analyses by the new method (Table I) show that removal of calcium from the serum is virtually complete after only two treatments with resin. Table II shows that protein and phosphate are only slightly altered, magnesium and potassium are almost completely removed, and serum sodium is increased, by three treatments with resin. Data provided by Sendroy (1944) and Smith, Craig, Bird, Boyle, Iseri, Jacobson, and

TABLE II

EFFECT OF RESIN TREATMENT ON SERUM CHEMISTRY

\begin{tabular}{|c|c|c|c|}
\hline \multirow[b]{2}{*}{ Constituent } & & \multicolumn{2}{|c|}{ Concentration } \\
\hline & & $\begin{array}{l}\text { Before Resin } \\
\text { Treatment }\end{array}$ & $\begin{array}{c}\text { After Resin } \\
\text { Treatment }\end{array}$ \\
\hline $\begin{array}{ll}\text { Protein (g.\%) } & \ldots \\
\text { Magnesium (mg.\%) } & \ldots \\
\text { Sodium (mEq./1.) } & \ldots \\
\text { Potassium (mEq./1.) } & \cdots \\
\text { Inorganic phosphorus (mg.\%) }\end{array}$ & $\begin{array}{l}\ldots \\
\cdots \\
\cdots \\
\ldots\end{array}$ & $\begin{array}{r}5 \cdot 6 \\
3 \cdot 4 \\
132 \\
3 \cdot 7 \\
3 \cdot 6\end{array}$ & $\begin{array}{c}5 \cdot 75 \\
0 \cdot 0 \\
159 \\
0 \cdot 1 \\
3 \cdot 7\end{array}$ \\
\hline
\end{tabular}

* There was no detectable difference in the electrophoretic pattern of untreated and treated sera.

Myers (1950), concerning the precipitation of calcium oxalate from serum, and by Llaurado (1954) on the amounts of sodium and potassium needed to produce detectable interference with the calcium flame, show that the changes observed in the concentrations of sodium and potassium could not have interfered with any subsequent procedure to which the standard sera were subjected. Magnesium does not interfere with flame-photometric serum calcium estimations (MacIntyre, 1957 ; Toribara, Dewey, and Warner, 1957), but it seemed possible that the removal of this element might make the serum unreliable as a standard for titrimetric procedures, since Smith et al. (1950) and MacIntyre (1957) have shown that some magnesium may be co-precipitated with calcium oxalate. However, the recovery of calcium in estimations on standard sera, using the Tisdall (1923) method, was unaltered by the addition of magnesium ( $3 \mathrm{mg} . / 100 \mathrm{ml}$.) to the sera.

Flame Photometric Procedure of Powell (1953). - The results in Table III (column 1a) show that this method gave low results with standard sera. Since Sendroy (1944) demonstrated complete precipitation of calcium oxalate under comparable conditions, contamination of the precipitate by a substance which depressed the calcium flame intensity was suspected.

Washing such precipitates improved the recovery of calcium, and the results after ashing were very close to the expected values (Table III, columns $1 \mathrm{~b}$ and 1c). This suggested that the contaminant was partially soluble. 
TABLE III

ESTIMATION OF CALCIUM IN STANDARD SERA BY VARIOUS METHODS

\begin{tabular}{|c|c|c|c|c|c|c|c|}
\hline \multirow{3}{*}{$\begin{array}{c}\text { Calcium } \\
\text { Content } \\
\text { of } \\
\text { Standard } \\
\text { Serum } \\
\text { (mg./100 } \\
\text { ml.) }\end{array}$} & \multicolumn{7}{|c|}{ Results (mg. $/ 100 \mathrm{ml}$ ) } \\
\hline & \multicolumn{3}{|c|}{ Method I } & \multicolumn{2}{|c|}{ Method II } & \multicolumn{2}{|c|}{ Method III } \\
\hline & (a) & (b) & (c) & (a) & (b) & (a) & (b) \\
\hline $8 \cdot 0$ & $\begin{array}{l}7 \cdot 3 \\
7 \cdot 0 \\
7 \cdot 1 \\
7 \cdot 3 \\
7 \cdot 1\end{array}$ & $\begin{array}{l}7.6 \\
- \\
-\end{array}$ & $\begin{array}{l}7 \cdot 8 \\
- \\
-\end{array}$ & $\begin{array}{l}7 \cdot 5 \\
= \\
-\end{array}$ & $\begin{array}{r}8 \cdot 3 \\
8 \cdot 0 \\
- \\
-\end{array}$ & E & $\begin{array}{r}7 \cdot 8 \\
8 \cdot 2 \\
- \\
- \\
\end{array}$ \\
\hline $10 \cdot 0$ & $\begin{array}{l}8 \cdot 7 \\
9 \cdot 2 \\
8 \cdot 7 \\
8 \cdot 4 \\
8 \cdot 7 \\
-\end{array}$ & $\begin{array}{l}9.0 \\
\text { - } \\
-\end{array}$ & $\begin{array}{l}9.8 \\
\text { - } \\
-\end{array}$ & $\begin{array}{l}9 \cdot 0 \\
9 \cdot 2 \\
9 \cdot 1 \\
9 \cdot 2 \\
9 \cdot 4 \\
\end{array}$ & $\begin{array}{r}9.9 \\
10.1 \\
9.9 \\
10 \cdot 1 \\
10 \cdot 2 \\
10 \cdot 0\end{array}$ & $\begin{array}{l}9 \cdot 0 \\
- \\
- \\
-\end{array}$ & $\begin{array}{r}10 \cdot 2 \\
10 \cdot 4 \\
10 \cdot 2 \\
9.9 \\
10 \cdot 2 \\
\end{array}$ \\
\hline $12 \cdot 0$ & $\begin{array}{l}10 \cdot 4 \\
11 \cdot 2 \\
10 \cdot 3 \\
11 \cdot 2 \\
10 \cdot 4 \\
11 \cdot 2\end{array}$ & $\begin{array}{c}11 \cdot 1 \\
\text { 二 } \\
\text { - }\end{array}$ & $\begin{array}{c}11.8 \\
- \\
-\end{array}$ & $\begin{array}{r}11 \cdot 5 \\
\text { - } \\
\text { - }\end{array}$ & $\begin{array}{r}12 \cdot 2 \\
\text { - } \\
\text { - }\end{array}$ & $\begin{array}{r}11.0 \\
- \\
- \\
-\end{array}$ & $\begin{array}{l}12.0 \\
12.1 \\
12.0 \\
11.9 \\
12.2 \\
-\end{array}$ \\
\hline $14 \cdot 0$ & $\begin{array}{r}13.2 \\
12.0 \\
- \\
-\end{array}$ & $\begin{array}{l}- \\
\text { - } \\
-\end{array}$ & - & - & $\begin{array}{r}14 \cdot 1 \\
- \\
-\end{array}$ & $\begin{array}{r}128 \\
- \\
-\end{array}$ & $\begin{array}{l}14.0 \\
13.9 \\
14.0 \\
13.9 \\
14.2\end{array}$ \\
\hline $16 \cdot 0$ & $\begin{array}{r}14.4 \\
13.5 \\
- \\
-\end{array}$ & $\begin{array}{l}- \\
- \\
-\end{array}$ & - & - & $\begin{array}{r}16 \cdot 2 \\
- \\
-\end{array}$ & $\begin{array}{r}14 \cdot 2 \\
- \\
-\end{array}$ & $\begin{array}{l}16 \cdot 3 \\
15 \cdot 7 \\
16 \cdot 3 \\
15 \cdot 9 \\
16 \cdot 1\end{array}$ \\
\hline
\end{tabular}

Methods: (1) Flame photometric (Powell). Precipitate (a) unwashed, (b) once washed, (c) ashed. (II) Titimetric (Tisdall). Precipitate washed with (a) dilute ammonia and (b) dilute ammonia saturated with calcium oxalate. (III) Improved flame photometric. (a) Without and (b) with addition of "triton $\mathrm{X}-100$ " to precipitant mixture.

Powell (1953) showed that the use of $0.05 \mathrm{~N}$ perchloric acid overcame depression of calcium flame intensity due to oxalate. This observation has been confirmed by experiments in which ammonium oxalate was added to a standard solution of calcium in amounts in excess of that likely to contaminate the calcium oxalate precipitate.

Similar experiments in which phosphate was added excluded it as the cause of the low recovery of calcium, a conclusion already indicated by the improved results obtained after ashing oxalate precipitates from serum.

The high concentration of protein in serum makes contamination of an unwashed calcium oxalate precipitate by protein inevitable. Furthermore, the proximity of the iso-electric point of serum globulin (about $p \mathrm{H} \mathrm{5.5)}$ to the $p \mathrm{H}$ of the precipitation mixture makes additional contamination by precipitation possible. The unwashed precipitate of calcium oxalate obtained in Powell's method was found to contain about $1.25 \mathrm{mg}$. of protein. A similar amount of protein remained in the centrifuge tube after centrifugation and decantation of decalcified serum treated with $p \mathrm{H}$ 5 oxalate buffer. Qualitatively, this protein was in the form of a precipitate together with a trace of serum/oxalate mixture. This was confirmed by paper electrophoresis (veronal buffer, $p H$ 8.6), the precipitate remaining at the site of application.

Addition of this protein-containing deposit from $2 \mathrm{ml}$. decalcified serum to $4 \mathrm{ml}$. of a standard calcium solution ( $\equiv 10 \mathrm{mg} . / 100 \mathrm{ml}$. serum calcium) depressed the flame photometer reading, giving an apparent calcium concentration of only 8.6 $\mathrm{mg}$./100 ml., a value almost identical with that found for the $10 \mathrm{mg} . / 100 \mathrm{ml}$. standard serum by Powell's method. The same effect was produced by adding serum globulin $(1.25 \mathrm{mg}$.) prepared from human serum by half-saturation with ammonium sulphate, but albumin $(1.25 \mathrm{mg}$. bovine albumin, Armour \& Co., Ltd., London) caused no depression of calcium flame intensity.

The Tisdall (1923) Method.-Powell found good agreement between results obtained by his flamephotometric method and by the titrimetric method of Tisdall (1923). This agreement is surprising since it was shown above that the flame photometric method gave low results on sera of known calcium content. However, low results have been obtained by Clark and Collip (1925), and MacIntyre (1957) with Tisdall's method due to loss of calcium oxalate during the two washings of the precipitate with dilute ammonia solution. Calcium determinations on standard sera (Table III, column 2a) confirmed that Tisdall's method gave low results, although the recoveries were not so poor as those obtained with Powell's flame photometric method. Figures close to the expected values (Table III, column 2 b) were obtained with the titrimetric procedure when dilute ammonia solution saturated with calcium oxalate (Stanford and Wheatley, 1925) was used to wash the precipitate.

These results show that Tisdall's titrimetric procedure is not valid as a standard for assessing other methods of calcium estimation.

Improved Flame Photometric Method.-The quantities of serum $(2 \mathrm{ml}$.), water $(4 \mathrm{ml}$.), and trichloroacetic acid $(4 \mathrm{ml}$.) recommended provide sufficient protein-free supernatant for duplicate estimations of both calcium and inorganic phosphorus. Sendroy (1944), Chen and Toribara (1954), and Severinghaus and Ferrebee (1950) found that a trichloroacetic acid extract contained all the serum calcium, and Sendroy (1944) noted that filtration of precipitated protein led to positive errors due to calcium impurities in filter papers. 
Ammonium acetate was added to the oxalate precipitant in order to effect precipitation of calcium oxalate from the trichloroacetic acid extract at $p \mathrm{H} 5$ as recommended by Sendroy (1944). The reproducibility and accuracy of estimations on standard sera were improved by the inclusion of "triton $\mathrm{X}-100$ " in the precipitation mixture (Table III, columns $3 a$ and $3 b$ ). The detergent was thought to prevent particles of the precipitate from sticking to the sides of the tube or floating on the surface of the mixture.

Kingsley and Schaffert (1954) showed that calcium flame intensity was increased by the addition of organic solvents to the spraying mixture. Using the EEL flame photometer, the emission of a standard calcium solution was approximately doubled by adding 0.25 volumes of acetone, and trebled by adding an equal volume of methanol or ethanol. Greater concentrations of solvent made the flame unstable.

Fig. 1 shows that a linear response was obtained over a four-fold range of calcium concentration (三 5-20 mg. Ca/100 ml. serum).

Results obtained with the improved method using sera of known calcium content are shown

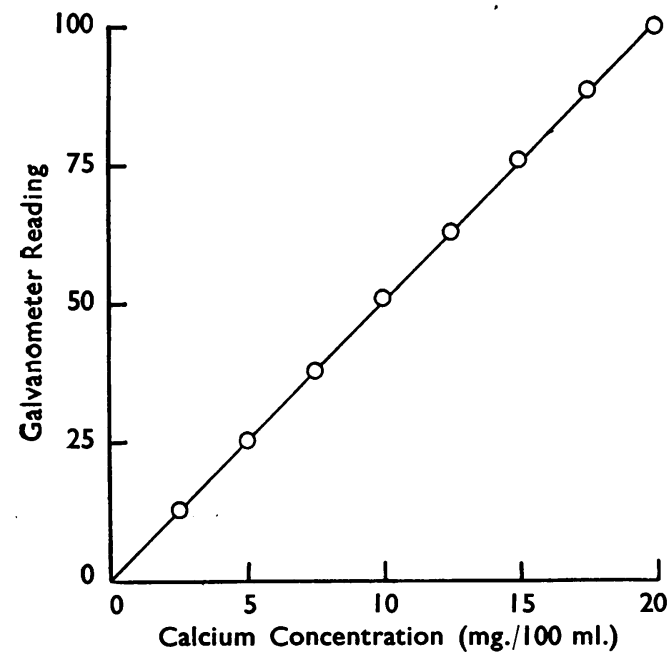

FIG. 1.-The effect of varying calcium concentrations on flame photometer readings. The standard solutions were sprayed after dilution as described for the working standard. Sensitivity was adjusted so that the $10 \mathrm{mg} . / 100 \mathrm{ml}$. standard gave a reading of 50 .
TABLE IV

RECOVERY OF CALCIUM ADDED TO URINE, FAECES, AND FOOD

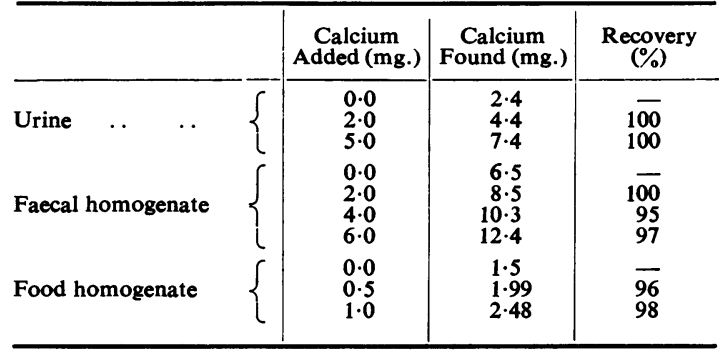

Additions were made to samples of urine $(100 \mathrm{ml}$.) or homogenate (5 g.).

in Table III (column 3b). Readings of duplicates agreed to within $4 \%$ and were usually identical.

The results of recovery experiments in which known amounts of calcium were added to urine or to homogenate of food or faeces are shown in Table IV.

Recoveries were excellent.

\section{Summary}

A method is described for the preparation of sera of known calcium content. It is shown, using these sera, that low results are given by Powell's (1953) method and Tisdall's (1923) method due respectively to contamination of the oxalate precipitate by protein and to washing losses. An improved method, using the EEL flame photometer, for the estimation of calcium in serum, urine, and faeces is described.

\section{REFERENCES}

Chen, P. S., and Toribara, T. Y. (1954). Analyt. Chem., 26, 1967. Clark, F. P., and Collip, J. B. (1925). J. biol. Chem., 63, 461.

Hussey, C. V., Quick, A. J., Stefanini, M., Consolazio, C. F., and Sargent, F. (1950). Ibid., 184, 105.

Kingsley, G. R., and Schaffert, R. R. (1954). Ibid., 206, 807.

Llaurado, J. G. (1954). J. clin. Path., 7, 110.

MacIntyre, I. (1957). Biochem. J., 67, 164.

Powell, F. J. N. (1953). J. clin. Path., 6, 286.

Sendroy, J. (1944). J. biol. Chem., 152, 539.

Severinghaus, J. W., and Ferrebee, J. W. (1950). Ibid., 187, 621.

Smith, R. G., Craig, Patricia, Bird, E. J., Boyle, A. J., Iseri, L. T. Jacobson, S. D., and Myers, G. B. (1950). Amer. J. clin. Path, 20, 263 .

Stanford, R. V., and Wheatley, A. H. M. (1925). Biochem. J., 19, 710. Stefanini, M. (1948). Proc. Soc. exp. Biol. (N.Y.), 67, 22.

Tisdall, F. F. (1923). J. biol. Chem., 56, 439.

Toribara, T. Y., Dewey, P. A., and Warner, H. (1957). Analyt. Chem., $29,540$. 